日作紀（Jpn. J. Crop Sci.）80（4）：391-402（2011）

\title{
研究論文
}

鼠淐

\section{定植前リン酸苗施用がキャベツとトウモロコシの生育初期の乾物生産, 光合成，根の活性および養分吸収に及ぼす影響}

\author{
渡邊和洋 ${ }^{1)}$ ・ 新野孝男 ${ }^{2)} \cdot$ 村山徹 $^{3)} \cdot$ 南條正巳 ${ }^{4)}$ \\ (1) 中央農業総合研究センター, ${ }^{2)}$ 農業生物資源研究所, ${ }^{3)}$ 東北農業研究センター, ${ }^{4}$ 東北大学農学部)
}

\begin{abstract}
要旨：定植前リン酸苗施用による定植後の初期生育の促進効果について, キャベッとトウモロコシを供試し, 乾物生 産特性, 光合成, 根の生理活性と伸長, および無機養分吸収の面から調査, 解析を行った。定植前リン酸苗施用により, 両作物とも, リン酸処理直後の 7〜14 日頃までは, 生育の促進は認められなかったが, その後の 1 2 週間に純同化 率（NAR）が高まることで, 生育が促進された。この NARが向上する期間は, 光合成速度も高くなった. 光合成速 度の増加には気孔コンダクタンスの増加が寄与していたが, トウモロコシでは葉身中のリン含有率の増加も重要な要 因であった，無機養分の吸収については,リンとカリ含有量が高まり, キャベッでは下位葉でも高く維持された。 また, 処理液に含まれるリンやカリだけでなく, マグネシウムなどの他の必須養分の吸収が促進されることもあった。一方, 呼吸速度や茎基部出液速度などの根の生理活性も高まる傾向が認められ，七ル苗のキャベッでは根の伸長も促進され た. 以上の結果から, リン酸の定植前苗施用は, リンの吸収を高めることで, 光合成拧よび根の生理活性を高め, 殊 にキャベッでは根の伸長も促進することで活着を早め, 茎葉への水と養分の供給を促進して高い光合成活性を維持し, 定植後の初期生育を促進しているものと考えられた.

キーワード：キャベッ，光合成，初期生育，定植前リン酸苗施用，トウモロコシ，養分吸収，リン酸.
\end{abstract}

リン酸肥料の原料であるリン鉱石は，近い将来の枯渴が 懸念されている資源である。 2009 年に扔ける全世界の資源 量は約 160 億卜ン，また年間総生産量 1 億 5800 万トンと 推定されており（U.S.Geological Survey 2010）, 今後も同じ ペースで採掘が進むと, その耐用年数は約 100 年と試算で きる。これに対し，BRICs 諸国やアジア，アフリカの途上 国に扔ける食料増産や, バイオマス作物の作付拡大に伴い, 近年肥料の需要は高まり，2008 年夏にかけ, リン酸をはじ めとする肥料価格が急騰した，その後の世界不況により， 肥料価格は幾分落ち着きを取り戻したが，今後とも高值基 調は続くものと考えられる。一方で, リン酸肥料の継続的 施用により, 土壤中へのリン酸の過剩蓄積 (小原・中井 2004）や，系外への流亡による水質污染（Sharpley 2003） が問題にもなってきている。 したがって，今後永続的に， かつ環境への負荷が少ない安定した農業生産を持続してい くためには, リン酸の効率的な施肥法の開発がますます重 要になっている.

著者らは, キャベッやトゥモロコシ（スイートコーン） 栽培に拈いて, 定植直前に $\mathrm{P}=0.5 \sim 1 \%$ のリン酸塩水溶液 を与えてから定植する「定植前リン酸苗施用法」により, リン酸の利用効率を高め, リン酸施肥量を大幅に削減でき ることを明らかにしてきた（渡邊ら 1997，2005，Watanabe et al. 2005)。また, リン酸施肥量を削減しても高い収量が
得られる要因として, 定植後 3 4 週間までの初期生育が 促進されることも重要であることを明らかにした，さらに， トウモロコシでは，定植前リン酸苗施用により，リンだけ でなく, マグネシウムや窒素などの無機養分の吸収が促進 されること, また定植後 3 週間前後の光合成速度が高まる ことなども報告してきた（Watanabe et al. 2005）。そこで本 報では，トウモロコシおよびキャべッを供試し，定植前リ ン酸苗施用により定植後 3 4 週間までの初期生育が促進 されるメカニズムについて，さらに詳細に明らかにするこ とを目的に，定植後の乾物増加，葉面積の展開，葉位別の 光合成関連形質の変化, マグネシウムなどの無機養分の吸 収, および根の伸長, 生理活性の面から解析をおこなった。

\section{材料および方法}

東北農業研究センター福島研究拠点 (一部試験は東北農 業試験場当時）において, キャベッのポット苗とセル成型 苗，およびトウモロコシのセル成型苗を供試して，3つの 試験を行った，試験により，処理方法, 調査項目に異なる 点があるので, 試験の概要を第 1 表にまとめた。なお，全 ての試験には, 福島研究拠点戋場から採取した淡色黒ボク 土を供試した。

2011 年 3 月 15 日受理。連絡責任者：渡邊和洋厂 $305-8666$ 茨城県つくば市観音台 3-1-1

TEL 029-838-8512, FAX 029-838-8527, nikonf2@affrc.go.jp 
第 1 表 各試験の処理条件, および調査測定項目.

\begin{tabular}{|c|c|c|c|c|}
\hline 試験 & & $\begin{array}{c}\text { 試 験 } 1 \\
\text { キャベッ ポット苗 }\end{array}$ & $\begin{array}{c}\text { 試 験 } 2 \\
\text { キャベッ } \quad \text { 七ル苗 }\end{array}$ & $\begin{aligned} \text { 試 } & \text { 験 } \\
\text { トウモロコシ } & \text { セル苗 }\end{aligned}$ \\
\hline \multirow{3}{*}{ 処理 } & 処理リン濃度 (P) & $0.92 \%$ & $0.5 \%$ & $1.0 \%$ \\
\hline & 基肥リン酸量 $\left(\mathrm{P}_{2} \mathrm{O}_{5}\right)$ & $0 \mathrm{~g} / \mathrm{m}^{2}$ & $9 \mathrm{~g} / \mathrm{m}^{2}$ （対照区の $50 \%$ ） & $0 \mathrm{~g} / \mathrm{m}^{2}$ \\
\hline & サンプリング調査日 & $\begin{array}{c}3 \text { 回 } \\
\text { 定植後 } 7,14,21 \text { 日 }\end{array}$ & $\begin{array}{c}2 \text { 回 } \\
\text { 定植後 } 15,27 \text { 日 }\end{array}$ & $\begin{array}{c}3 \text { 回 } \\
\text { 定植後 } 9,17,24 \text { 日 }\end{array}$ \\
\hline \multirow{7}{*}{ 測定項目 } & 部位別乾物重 & ○(葉位別) & $\bigcirc$ & 0 \\
\hline & 葉面積 & ○(葉位別) & O & O \\
\hline & 根長 & $\times$ & 0 & 0 \\
\hline & 茎基部出液量 & $x$ & 0 & 0 \\
\hline & 根呼吸速度 & $x$ & O & O \\
\hline & 無機養分含有量 & $\mathrm{P}, \mathrm{K}, \mathrm{Mg}, \mathrm{Ca}, \mathrm{N}$ & $x$ & $\mathrm{P}, \mathrm{K}, \mathrm{Mg}, \mathrm{Ca}$ \\
\hline & 光合成速度 & ○(葉位別) & $x$ & 0 \\
\hline
\end{tabular}

\section{1. 供試作物の栽培およびリン酸処理}

(1) 試験 1 : キャベッ, ポット苗

キャベッ（品種：秋蒔極早生 2 号）種子を，2001年 1 月 10 日に市販の園芸用粒状培土 $\left(\mathrm{N}=0.4 \mathrm{~g}, \mathrm{P}_{2} \mathrm{O}_{5}=1.5 \mathrm{~g}\right.$, $\mathrm{K}_{2} \mathrm{O}=0.4 \mathrm{~g}, \mathrm{MgO}=0.2 \mathrm{~g} \mathrm{~kg}^{-1}$ 含有) を $150 \mathrm{~g}$ ずつ充填し たビニールポットに播種し，最低気温を $20^{\circ} \mathrm{C}$ に設定した ガラス温室で第 3 葉が展開し始めるまで育苗した，定植前 リン酸苗施用は，2月 4 日に渡邊らの既報（2005）と同様 に行った。すなわち，第 1 リン酸カリと第 2 リン酸カリを モル比で $3: 1$ に混合し, リン濃度を $\mathrm{P}=0.92 \%, \mathrm{pH}=6.2$ に調整したリン酸カリ水溶液を各苗 $40 \mathrm{~mL}$ 施用した。この 施用量は，苗あたり $\mathrm{P}=0.377 \mathrm{~g}$ にあたり，これは慣行の リン酸施用量 $\left(\mathrm{P}_{2} \mathrm{O}_{5}=18 \mathrm{~kg} / 10 \mathrm{a}\right.$ 相当）と栽植密度（4167 株 $/ 10$ a）から換算した株あたりリン酸施用量の $20 \%$ に相 当する。この苗をリン酸無施用の $1 / 5000$ a ワグナーポット に 1 個体ずつ移植した（P0区），比較のため無処理苗を慣 行の施肥量のポットに 1 株ずつ定植した（C100区）。また 両処理区とも $\mathrm{N}$ は $25 \mathrm{~kg} / 10 \mathrm{a} ， \mathrm{~K}_{2} \mathrm{O}$ は $15 \mathrm{~kg} / 10 \mathrm{a}$ ，苦土石 灰は $100 \mathrm{~kg} / 10 \mathrm{a}$ 相当量を施用した. 定植後は人工気象器内 (明期 / 暗期 : 13/11 時間, 光強度 : 400 $600 \mu \mathrm{mol} \mathrm{m}^{-2} \mathrm{~s}^{-1}$, 温度: $20 / 15^{\circ} \mathrm{C}$, 相対湿度: $60 / 80 \%$ ）で栽培し，定植後 7 日， 14 日および 21 日目に両区 6 個体ずつサンプリングを行い, 調查に供した。

\section{（2） 試験 2：キャベツ，セル成型苗}

キャベッ（品種：秋蒔極早生 2 号）種子を，2004 年 1 月 5 日にセル成型苗用育苗培土（バーミキュライト+バーク， $\mathrm{N}=0.2 \mathrm{~g}, \mathrm{P}_{2} \mathrm{O}_{5}=2.8 \mathrm{~g}, \mathrm{~K}_{2} \mathrm{O}=0.5 \mathrm{~g} \mathrm{~L}^{-1}$ 含有）を充填し た 128 穴のセルトレイに播種し, 最低気温を $20^{\circ} \mathrm{C}$ に設定し たガラス温室で第 3 葉が展開し始めるまで育苗した。定植 前リン酸苗施用は，2 月 4 日に Watanabe et al.（2005）に準 じて行った。すなわち， $\mathrm{P}=0.5 \%$ のリン酸カリウム水溶 液をコンテナ内でセルトレイ上から掛け流し，その後 1 時 間浸漬した。この苗を慣行のリン酸施肥量, $\mathrm{P}_{2} \mathrm{O}_{5}=18$ $\mathrm{kg} / 10 \mathrm{a}$ の $50 \%$ にあたる $\mathrm{P}_{2} \mathrm{O}_{5}=9 \mathrm{~kg} / 10 \mathrm{a}$ 相当を施用した
$30 \mathrm{~cm} \times 30 \mathrm{~cm} \times 10 \mathrm{~cm}$ のコンテナに 4 個体ずつ定植した (P50区). 比較のため無処理苗を慣行の施肥量のコンテナ に定植した（C100区）。また両処理区とも N は $25 \mathrm{~kg} / 10 \mathrm{a}$, $\mathrm{K}_{2} \mathrm{O}$ は $15 \mathrm{~kg} / 10 \mathrm{a}$, 苦土石灰は $100 \mathrm{~kg} / 10$ a 相当量を施用した。 定植後もガラス温室で栽培し, 定植後 15 日および 27 日目 に両区 12 個体ずつサンプリングを行い，調査に供した．

（3） 試験 3 ：トウモロコシ, セル成型苗

トウモロコシ（品種：ピーターコーン）種子を，2003 年 5 月 28 日にセル成型苗用育苗培土を充填した 128 穴の七 ルトレイに 1 粒ずつ播種し, 網室で第 3 葉が抽出するまで 育苗した。定植前リン酸苗施用は， 6 月 16 日に試験 2 と 同様に行った。ただし，処理リン濃度を $\mathrm{P}=1.0 \%$ とした。 この苗をリン酸無施用のポットに 1 個体ずつ定植した（P0 区)．比較のため無処理苗を慣行の施肥量 $\left(\mathrm{P}_{2} \mathrm{O}_{5}=12 \mathrm{~kg} / 10\right.$ $\mathrm{a}$ 相当）のポットに 1 株ずつ定植した（C100区）。なお， 1 回目と 2 回目の調查用の個体は $1 / 5000 \mathrm{a}$ ポットに, 3 回目 の調査用の個体は $1 / 2000 \mathrm{a}$ ポットに定植した。 また, 両処 理区とも $\mathrm{N}$ および $\mathrm{K}_{2} \mathrm{O}$ は $15 \mathrm{~kg} / 10 \mathrm{a}$ ，苦土石灰は 100 $\mathrm{kg} / 10 \mathrm{a}$ 相当量を施用した. 定植後は網室で栽培し, 定植後 9 日，17日拈よび 24 日目に両区 6 個体ずつサンプリング を行い, 調査に供した。

\section{2. 調査・測定項目}

\section{（1）茎基部出液量}

トウモロコシでは 6 個体全て，七ル成型苗キャベッでは 両区 8 個体について, 小柳（1995），山口ら（1995），森田 ら（1999）に準じて出液量を測定した。すなわち，土壤表 面から約 $1 \mathrm{~cm}$ の高さで茎葉部を切断し, あらかじめ重量 を測定しておいた脱脂綿を切り口にあて，トゥモロコシで は 4 時間，キャベッでは 3 時間出液を吸収させ，測定前後 の重量変化から茎基部出液量を求めた。 上記に引用した 3 つの報告では，比較的生育が進んだ個体を対象にしている ため，測定時間が 1 時間となっているが，本試験で用いた のは定植から間もない若い個体であり, 出液の絶対量が少 

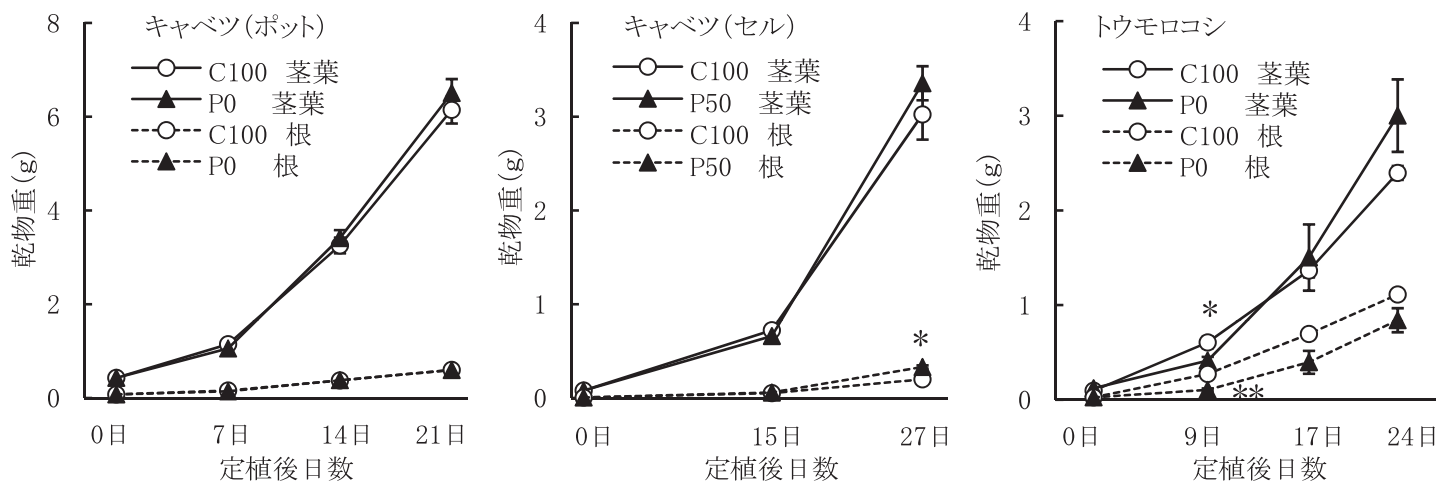

第 1 図 定植前リン酸苗施用が茎葉抢よび根の乾物重に及ぼす影響.

図中のバーは標準誤差を，*，**はそれぞれ $5 \% ， 1 \%$ 水準で処理間に有意差があることを示す，

ないため，測定時間を長めに設定した。いずれも十分灌水 して, 午前 9 時頃から測定を開始した。なお, ポット苗キャ ベッでは出液量の測定は行わなかった.

\section{（2）根呼吸速度および根長}

トウモロコシでは 6 個体について出液量測定後, セル成 型苗のキャベッでは出液量測定に用いなかった 4 個体につ いて, 直径が約 $1 \mathrm{~mm}$ 以下の細根とそれ以上の太根に分け, そのうち細根のみを呼吸速度の測定に供した，根の呼吸速 度は $\mathrm{O}_{2}$ アップテスター（タイテック社）を用いたマノメー ター法で測定した。測定時の温度は，キャベッでは $20^{\circ} \mathrm{C}$, トウモロコシでは $22.5^{\circ} \mathrm{C}$ とし，ブランク值が安定してか ら 3 4 時間の間の 30 分ごとに $\mathrm{CO}_{2}$ 放出量を記録した.

呼吸速度測定後, 細根についてはルートスキャナ (Comair 社）を用いて根長を測定した。またトウモロコシの太根に ついては物差しで根長を測定した。主根型の根系をもつ キャベッについては，太根の根長は測定しなかった。

\section{（3）生育調査および生長解析}

地上部については, キャベッでは, 葉身, 中肋を含む葉 柄＋荎（以下「葉柄＋荎」）に，トウモロコシでは，葉身， 葉鞘＋菱に切り分け，それぞれ葉身については葉面積を 測定した。なお，ポット苗キャベッの葉身については，葉 位ごとに測定を行った。また，根長を測定した根について は $0.1 \mathrm{~mm}$ 目の篩で回収し, それぞれ $80^{\circ} \mathrm{C} て ゙ 48$ 時間乾燥し, 部位別の乾物重を測定した。そして，葉面積と乾物重の值 を用いて生長解析を行い, 各生育期間の相対生長率 (RGR), 純同化率 (NAR)，および葉面積比（LAR）を算出した。

\section{（4） 光合成速度・気孔コンダクタンス}

ポット苗キャベッでは展開している各葉位について, 卜 ウモロコシは最上位展開葉について, 個葉の光合成速度お よび気孔コンダクタンスを携带型光合成測定装置 (LI-6200, Li-cor 社）を用いて測定した，キャベッでは，定植後 2 日， 6 日，13 日，20日後の 4 回，トゥモロコシでは，定植後 8 日後, 16 日後の 2 回, それぞれメタルハライドランプ光 源下で測定を行った。測定時の光量子密度, 温度, $\mathrm{CO}_{2}$ 濃 度は，それぞれ，キャベッでは，940〜980 $\mu \mathrm{mol} \mathrm{m}^{-2} \mathrm{~s}^{-1}, 23$ $\sim 26{ }^{\circ} \mathrm{C}, 370 \mu \mathrm{mol} \mathrm{mol}^{-1}$, トゥモロコシでは, 850〜880 $\mu \mathrm{mol} \mathrm{m} \mathrm{s}^{-1}, 27 \sim 30^{\circ} \mathrm{C}, 380 \mu \mathrm{mol} \mathrm{mol}^{-1}$ であった.

\section{（5） 無機養分含有量}

ポット苗キャベツおよびトウモロコシについて, 乾物重 測定後の葉身扮よび葉鞘+荎または葉柄のサンプルを粉砕 し, 無機養分分析に供した。リン $(\mathrm{P})$, カリウム $(\mathrm{K})$, カルシウム $(\mathrm{Ca})$ ，マグネシウム $(\mathrm{Mg})$ については, 硝酸 分解 (小山 1990) の後, ICP 発光分析法 (ICPS-8000, 島津) で定量した，定植後 21 日目のポット苗キャベッの全窒素 （N）については，CN コーダー（MT-600, 柳本）で定量し た。また，トウモロコシでは光合成速度を測定した最上位 展開葉について, SPAD 值を求めた（SPAD-501, ミノルタ).

結果

\section{1. 生育}

定植前リン酸苗施用を行ったときの乾物重の変化をそれ ぞれ第 1 図に示した。茎葉＝地上部の乾物重は，キャベツ では定植前リン酸苗施用（以下，リン酸処理と記載）の影 響は明瞭ではなかった。ただし，調査終了時のポット苗の 21 日目，セル成型苗の 27 日目では, リン酸処理により乾 物重が若干大きくなる傾向があり，既報の圑場試験で認め られた定植後 21〜22 日目（渡邊ら 1997）または 27 日目（渡 邊ら 2005）における初期生育の増加に対応するものと考え られた。

一方, トウモロコシの地上部乾物重は, 定植後 9 日目には, リン酸処理により小さくなった。 その後, 定植後 17 日目 までには，リン酸処理区の生育は回復し，24 日目には有 意差は認められなかったものの，既報（Watanabe et al. 2005）の圃場試験と同様にリン酸処理区で乾物重が大きく なる傾向を示した。

また，葉面積も第 2 図に示したように地上部乾物重と同 様に推移した。第 3 図に, ポット苗キャベッの生育期間ご との葉面積の増加量を葉位別に示したＰ０区の葉面積の 増加量は, 定植直後の 7 日間は, 全ての葉位で $\mathrm{C} 100$ 区に 比べ小さい傾向が認められたのに対し，これに続く定植後 7〜14 日は, 逆に全ての葉位で大きくなった。 その結果, 定植 14 日後の葉面積は全ての葉位で C100 区より大きくな 

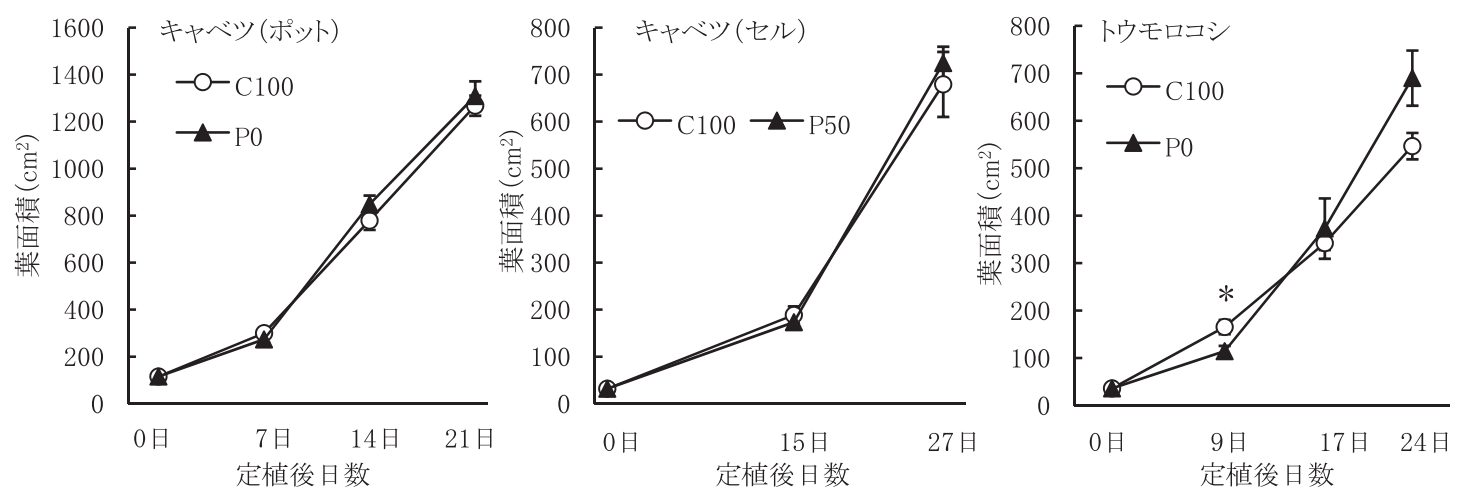

第 2 図定植前リン酸苗施用が葉面積に及ぼす影響.

図中のバーは標準誤差を，*は 5\%水準で処理間に有意差があることを示す.
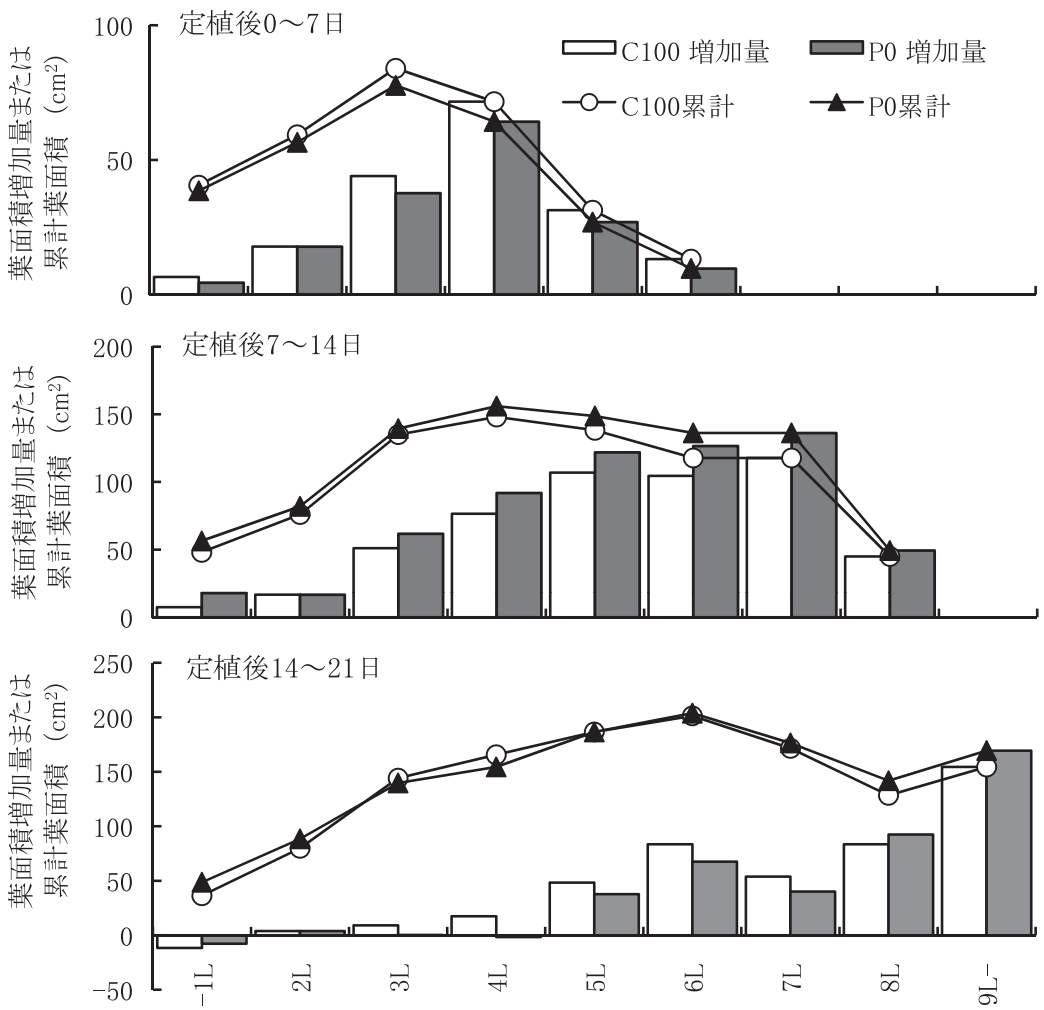

第 3 図 ポット苗キャベツに定植前リン酸苗施用を行ったときの生育期間ごとの葉位 別葉面積の増加量および各生育期末までの累積葉面積.

$-1 \mathrm{~L}$ には子葉，定植時の $3 \mathrm{~L}$ には第 $4 ， 5$ 葉， 7 日後の $6 \mathrm{~L}$ には第 7,8 葉，14 日 後の $8 \mathrm{~L}$ には第 $9 ， 10$ 葉，21 日後の $9 \mathrm{~L}-に は$ 第 $10 〜 13$ 葉をそれぞれ含む.

る傾向が認められた。ささに続く定植後 14〜21日は，中 位葉（第 3〜 7葉）では, C100 区で葉面積の増加が大きく, 最終的な葉位別葉面積は処理間に差が認められなくなっ た。これに対し，上位葉（第 8 葉，9 葉以上）では，引き 続き $\mathrm{P} 0$ 区の葉面積増加量が大きかった。

一方，第 1 図の破線に示した根の乾物重，および第 4 図 に示した根長に対する定植前リン酸苗施用の効果には種間 差が認められた。ポット苗キャベッでは，処理期間中，根 の乾物重には処理間で差は認められなかった。またセル成 型苗キャベッでは，定植後 15 日目は処理間に差は認めら
れなかったが，27日目には乾物重，根長ともリン酸処理 区で大きくなった。これに対し，トウモロコシでは，定植 後 9 日目には, P0 区で根の生育は著しく抑制され, 乾物重, 根長ともC100 区の $50 \%$ 以下にとどまった，その後生育が 進むにともない，P0 区の $\mathrm{C} 100$ 区に対する抑制の程度は小 さくなったが，定植後 24 日目には C100 区並みまでは回復 しなかったなな第 4 図中に示したように，全根長に対す る $1 \mathrm{~mm}$ 以下の細根が占める割合は，定植前リン酸苗施用 の影響は受けなかった。

これらの結果を基に生長解析を行い，生育期間ごとの 

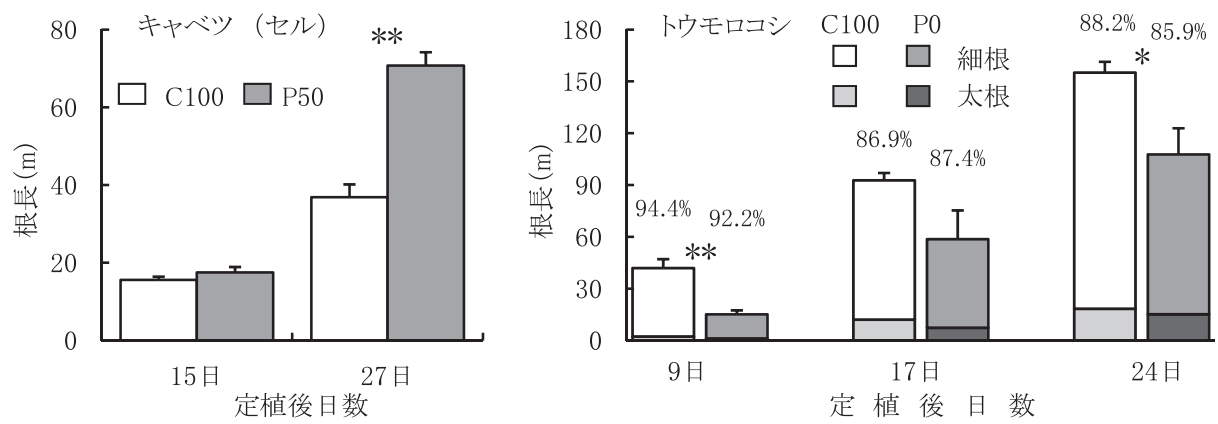

第 4 図＼cjkstart定植前リン酸苗施用が根長に及ぼす影響

図中のバーは, 標準誤差を,*，**はそれぞれ $5 \%, 1 \%$ 水準で処理間に有意差があることを示す. トウモロコシの図中の数值は, 全根長に対する細根の割合を示す.
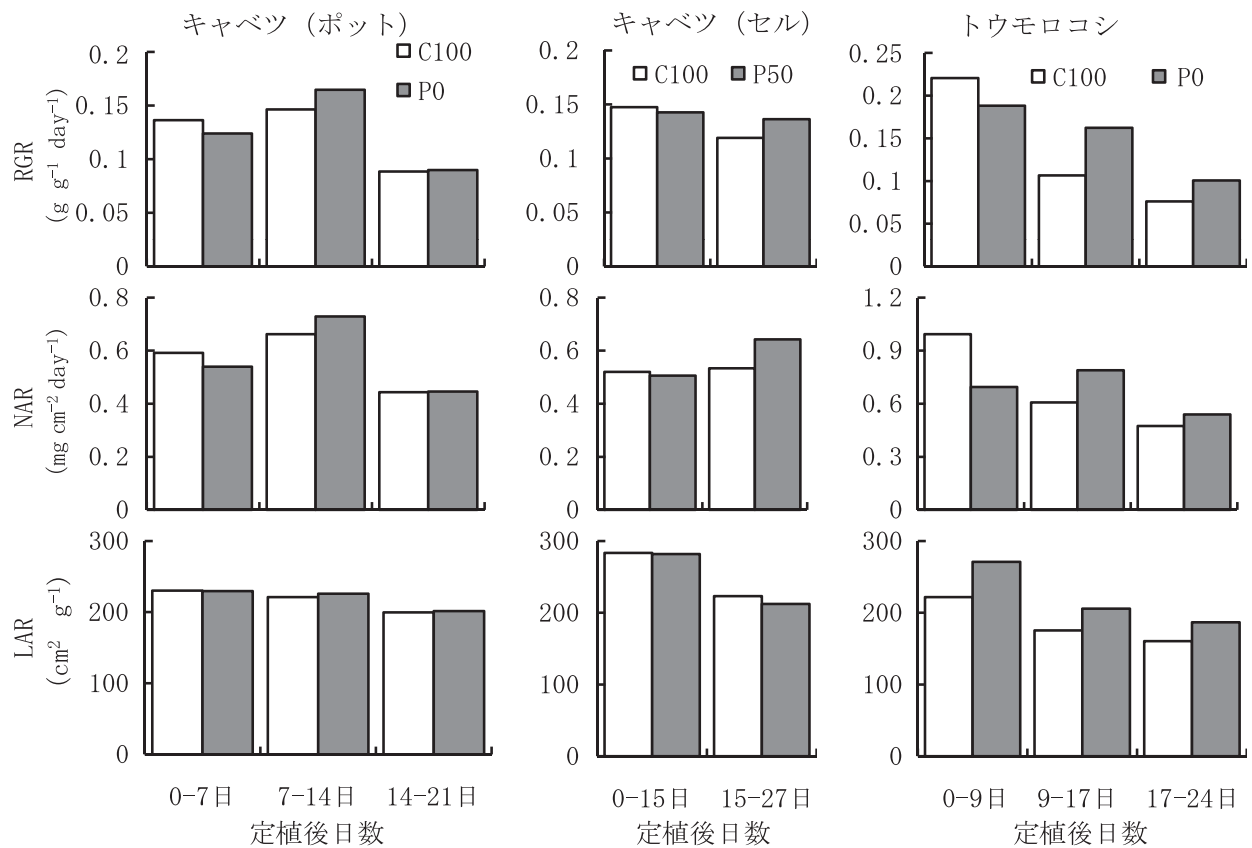

第 5 図 定植前リン酸苗施用を行ったときの相対生長率 (RGR), 純同化率 (NAR) および葉面積比 (LAR) の変化.

RGR，NAR，LAR 第 5 図に示した。ポット苗キャベッ では, 定植後 0〜7日の期間に P0区で RGRがやや低かった. LAR は処理間に差が認められなかったので, NARの低下 がその要因であった。 これに続く定植後 7〜14 日の期間の RGR は，P0 区で高くなったが，ここでも LAR は処理間に 差が認めらなかったため，この期間にP0 区で RGR が高く なったことには，NARが高くなったことが寄与していた． さらに定植後 14〜21日の期間では，RGR，NAR， LAR と も処理間に差は認められなくなった。

セル成型苗キャベツは，定植後 0１5 日日では，全乾物 重に処理間に差が認められなかったので, この間の RGR も処理間でほぼ同程度であった。また，RGRの構成要素 の NAR と LAR にも処理間で顕著な差異は認められなかっ た。しかし，それに続く定植後 15２7日には，乾物重は P50 区がC100 区より大きくなったため, RGR も P50 区で
高くなった.リン酸処理により，この期間の LAR はわず かに減少したが, NAR は顕著に高くなった。

トウモロコシでは，RGR は定植後 0９日にはP0 区が C100区より低くなった。 トウモロコシでは, キャベッと 異なり,リン酸処理による根の生育抑制が茎葉に比べて顕 著なため, 地上部への乾物分配割合が高まり, LAR は高かっ たが，NARの低下の程度がそれ以上に大きかったため, 結果的に RGR は低下した。 それに続く定植後 9 17 日の 生育期間には，キャベッ同様に，リン酸処理により NAR が高くなり，結果として RGRが高かった，LARにおける 処理間差は, 定植後 0〜 7 日に比べて小さかったものの, 依然として P0 区で高かったことも, RGR の増加の要因で あった，定植後 17〜27 日の生育期間にあっても，NAR， LAR とも依然として P0区で高く維持され, 結果として RGR も高かった. 


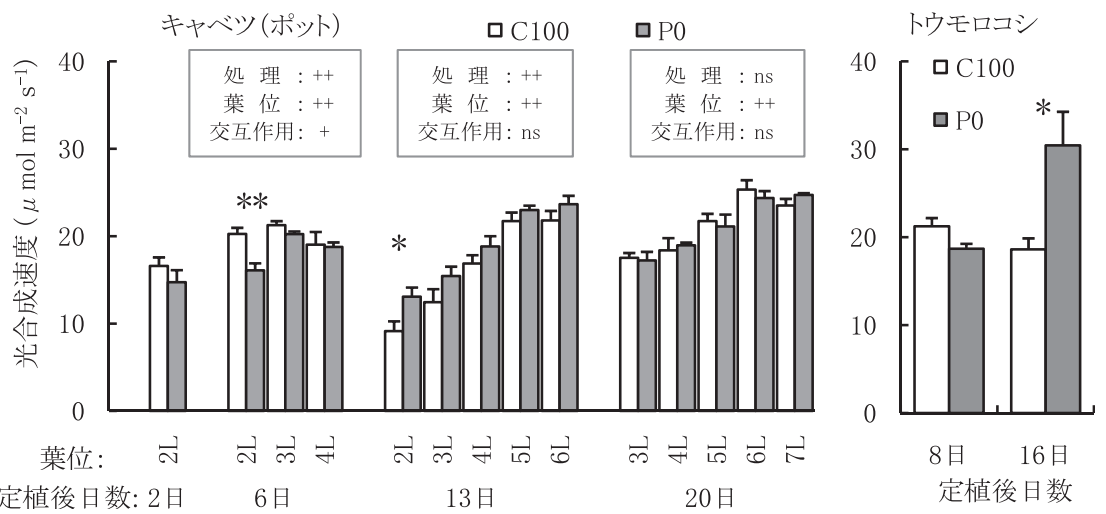

第 6 図 定植前リン酸苗施用を行ったときの光合成速度の変化.

図中のバーは標準誤差を，*，**はそれぞれ 5\%, 1\%水準で葉位毎に処理間で有意差 があることを, また左図の枠内の,,$+++ \mathrm{ns}$ は分散分析の結果, 各要因効果, 交互 作用がそれぞれ $5 \%, 1 \%$ 水準で有意，有意でないことを示す。
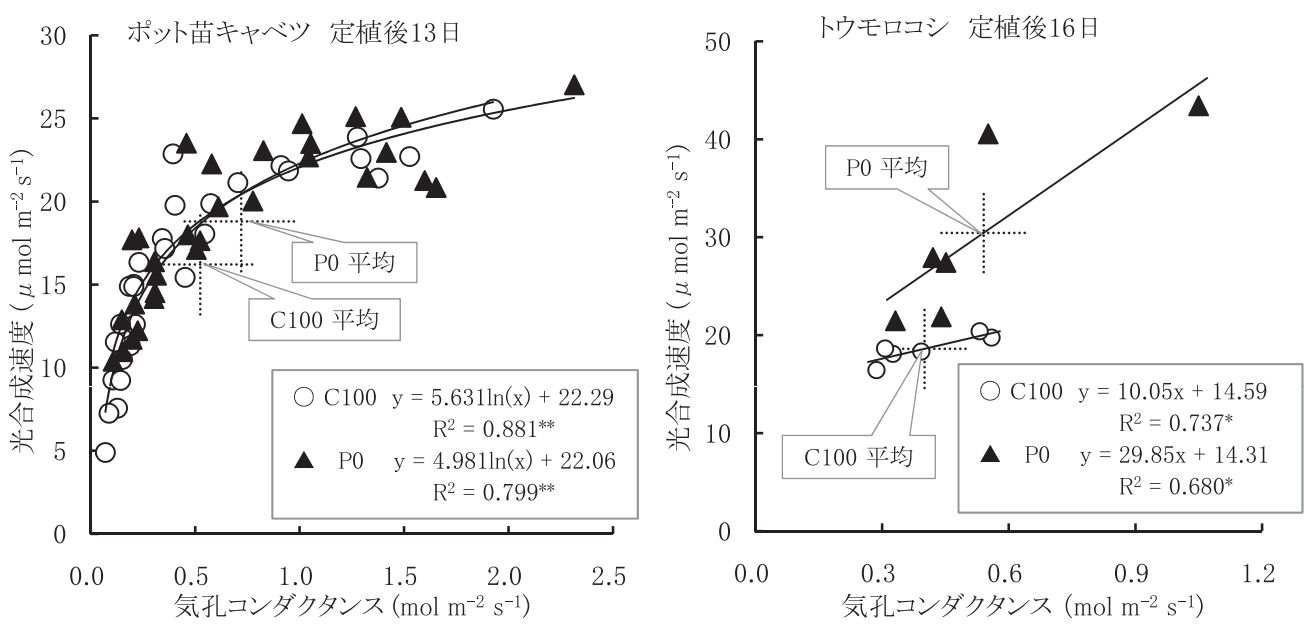

第 7 図定植前リン酸苗施用を行ったときの気孔コンダクタンスと光合成速度との関係

図中の*，***それぞれ $5 \%, 1 \%$ 水準で有意であることを示す.

\section{2. 光合成速度}

定植前リン酸苗施用を行ったときの光合成速度の変化を 第 6 図に示した。

ポット苗キャベッの光合成速度は, 定植 2 日後, および 6 日後ではリン酸処理によりやや低下する傾向を示した。 これに対し, 定植 13 日後について葉位毎に $\mathrm{t}$ 検定を行うと, 測定葉の中で最下位の第 2 葉以外は処理間に有意差が認め られなかったが，施肥法と葉位を要因とする 2 元配置の分 散分析を行うと，光合成速度はリン酸処理で有意に高まっ た（リン酸処理 $: p=0.001$, 葉位 $: p=0.000$, 交互作用: $\mathrm{p}=0.742)$. しかし，定植後 20 日後では，処理による差 は認められなかった。

トウモロコシでも，光合成速度は，リン酸処理区で定植 8 日後ではやや低い值を示したが，16 日後には無処理区の 1.6 倍となり有意に高かった。

定植前リン酸苗施用により光合成速度が高まったポット キャベッの定植後 13 日目およびトウモロコシの定植後 16
日目の気孔コンダクタンスと光合成速度との関係を第 7 図 に示した。両作物とも気孔コンダクタンスが大きくなるこ とにより光合成速度が高まる関係が認められた。キャべッ では，気孔コンダクタンスと光合成速度は C100 区，P0 区 とも曲線に回帰し，それぞれの回帰式には有意差が認めら れなかったことから，定植前リン酸苗施用は，定植後 13 日目のキャベッでは気孔コンダクタンスと光合成速度との 関係には影響しなかった。しかし，気孔コンダクタンスの 平均值は，P0 区が $\mathrm{C} 100$ 区に比べて大きいことから，光合 成速度も P0 区が $\mathrm{C} 100$ 区より高かった。

一方，トウモロコシでは，C100 区，P0区とも直線に回 帰し，2つの回帰直線の回帰係数には有意差は認められな かった（ $\mathrm{p}=0.295 ）$. すなわち, トウモロコシでもリン酸 処理の有無にかかわらず気孔コンダクタンスの増加に伴い 光合成速度も高まる関係が認められ，気孔コンダクタンス の平均值が $\mathrm{C} 100$ 区よりも $\mathrm{P} 0$ 区が大きかったことが，光 合成速度が高かった要因の 1 つであった，次に共通の回帰 

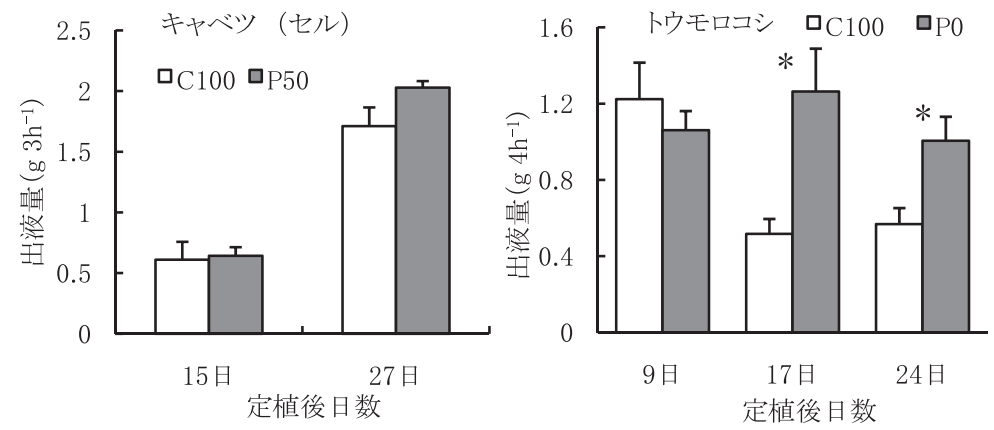

第 8 図＼cjkstart定植前リン酸苗施用を行ったときの茎基部出液量の変化.

図中のバーは標準誤差を, *は 5\%水準で処理間に有意差があることを示す.
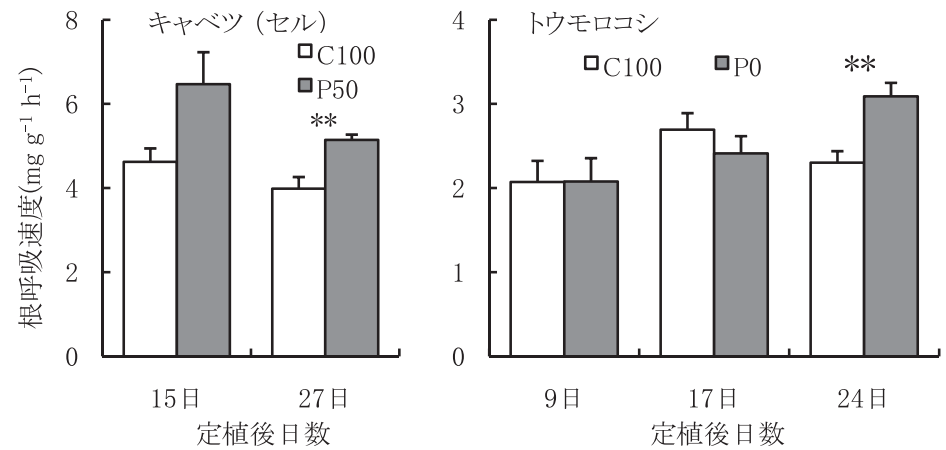

第 9 図 定植前リン酸苗施用を行ったときの細根重あたりの根の呼吸速度. 図中のバーは標準誤差を，*，**はそれぞれ $5 \%, 1 \%$ 水準で処理間に 有意差があることを示す。

係数を持つ回帰直線を求めると, $\mathrm{C} 100$ 区: $\mathrm{y}=26.4 \mathrm{x}+8.02$, $\mathrm{P} 0$ 区: $\mathrm{y}=26.4 \mathrm{x}+16.15$ となったが，回帰定数 8.02 と 16.15の間には有意差が認められた $(\mathrm{p}=0.013)$.すなわち, P0 区で光合成速度が高かった要因は，気孔コンダクタン スの増大以外にも存在することが示唆された.

\section{3. 茎基部出液量, 出液速度}

第 8 図に示したように, 個体あたりの出液量は, セル成 型苗キャベッでは，処理区による有意差は認められなかっ たが，定植 27 日後にはP50 区で多くなる傾向を示した $(\mathrm{p}=0.085)$. トゥモロコシでは，定植 9 日後は処理間の差 は明瞭でなかったが, 17 日後, 24 日後は P0 区で多くなった.
一方, 出液量を細根重で除して求めた細根重あたりの出 液速度は, トウモロコシではリン酸処理により細根重が小 さかったため,いずれの調査日に捛いても顕著に高まった. キャベッでは,リン酸処理により細根重が逆に大きかった ため，細根重あたりの出液速度は低くなる傾向が認められ た（図表省略）。

\section{4. 根の呼吸速度}

セル成型苗キャベッの根の呼吸速度は，第 9 図に示した ように，定植 27 日後には P50 区が 100 区より高かった. 定植 15 日後は，5\%水準で処理間に有意差は認められな かったが，危険率を $10 \%$ 水準とすると P50 区で高い傾向

第 2 表 定植前リン酸苗施用を行ったときの各作物の茥葉中の無機養分含有量.

\begin{tabular}{|c|c|c|c|c|c|c|c|c|c|c|c|c|c|c|c|}
\hline & \multirow{2}{*}{$\begin{array}{c}\text { 定植後 } \\
\text { 日数 }\end{array}$} & \multicolumn{3}{|c|}{ P（mg/茎葉） } & \multicolumn{3}{|c|}{ K（mg/茎葉） } & \multicolumn{3}{|c|}{$\mathrm{Mg}$ (mg/茎葉) } & \multicolumn{3}{|c|}{$\mathrm{Ca}$ (mg/茎葉) } & \multicolumn{2}{|c|}{$\mathrm{N}$ （mg/茎葉） } \\
\hline & & C100 & $\mathrm{P} 0$ & $\mathrm{t}$ & $\mathrm{C} 100$ & P0 & $\mathrm{t}$ & $\mathrm{C} 100$ & $\mathrm{P} 0$ & $\mathrm{t}$ & C100 & $\mathrm{P} 0$ & $\mathrm{t}$ & $\mathrm{C} 100$ & $\mathrm{P} 0$ \\
\hline \multirow{3}{*}{$\begin{array}{l}\text { キャベッ } \\
\text { (ポット) }\end{array}$} & 7 日 & 5.9 & 7.2 & $*$ & 43.2 & 45.5 & & 4.0 & 3.5 & & 21.3 & 18.5 & & - & - \\
\hline & 14 日 & 11.8 & 20.7 & $* *$ & 122.2 & 147.5 & $*$ & 12.7 & 14.0 & & 65.1 & 71.4 & & - & - \\
\hline & 21 日 & 21.5 & 37.5 & $* *$ & 220.8 & 251.7 & & 22.3 & 21.5 & & 101.9 & 101.4 & & 320.2 & 329.2 \\
\hline \multirow{3}{*}{ トウモロコシ } & 9 日 & 2.04 & 3.78 & $* *$ & 31.3 & 24.0 & & 0.85 & 0.57 & $*$ & 2.28 & 1.28 & * & - & - \\
\hline & 17 日 & 2.15 & 4.00 & $* *$ & 58.9 & 73.0 & & 1.71 & 1.67 & & 3.22 & 2.63 & & - & - \\
\hline & 24 日 & 3.20 & 4.83 & $*$ & 104.8 & 144.9 & $*$ & 2.71 & 3.06 & & 4.44 & 4.17 & & - & - \\
\hline
\end{tabular}

表中の*，**は， t 検定でそれぞれ $5 \% ， 1 \%$ 水準で処理間に有意差があることを示す 
第 3 表 ポット苗キャベツに定植前リン酸苗施用を行ったときの葉位別の無機養分含有率.

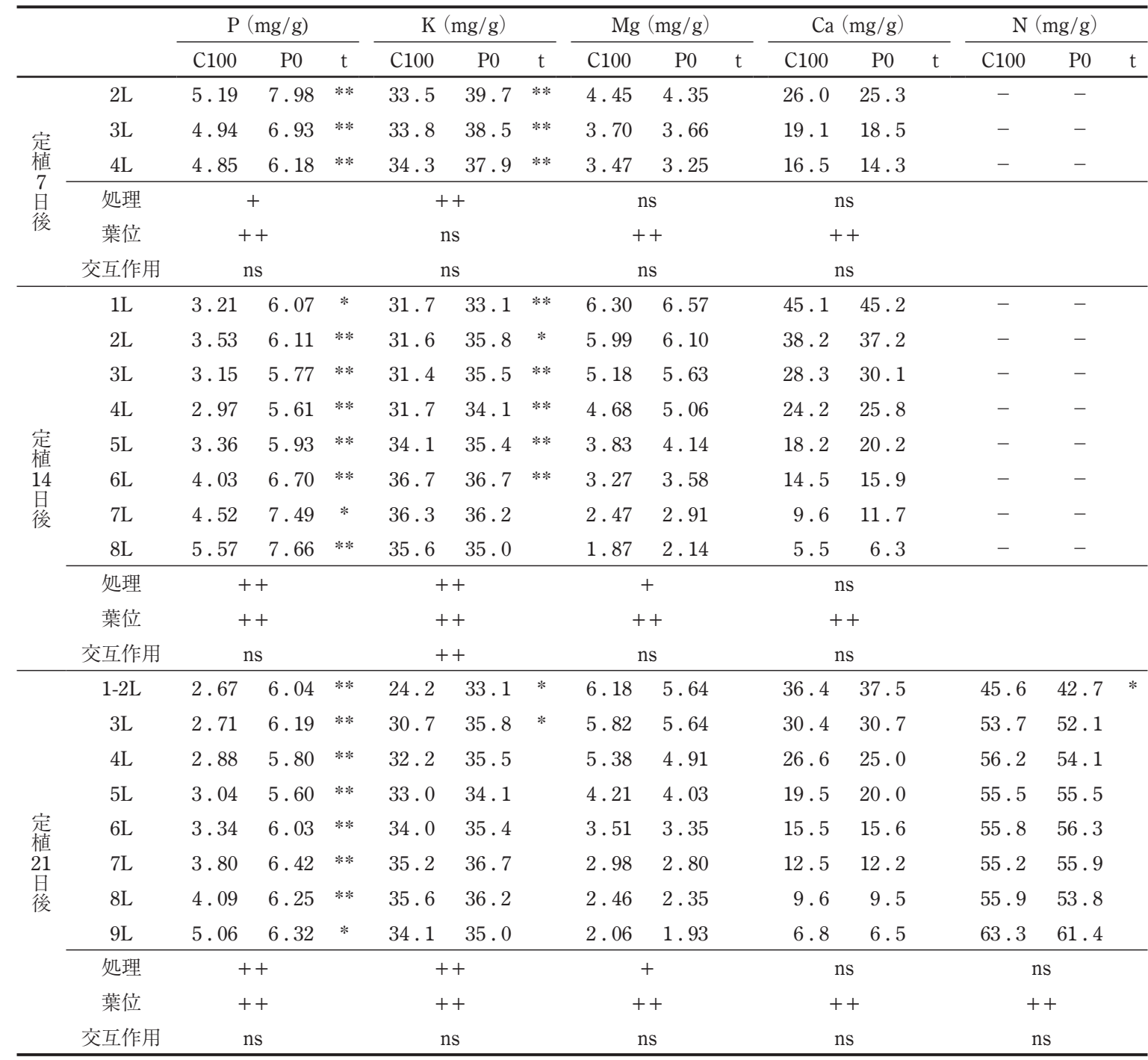

表中の*，**は， t 検定でそれぞれ各葉位毎に処理間に $5 \%, 1 \%$ 水準で有意差があることを，+, ++, ns は分散分析の結果， 各要因効果，交互作用がそれぞれ 5\%, 1\%水準で有意，有意でないことを示す．

第 4 表 トウモロコシに定植前リン酸苗施用を行ったときの葉身中の無機養分含有率およびSPAD 值

\begin{tabular}{|c|c|c|c|c|c|c|c|c|c|c|c|c|c|c|c|}
\hline \multirow{2}{*}{ 定植後 } & \multicolumn{3}{|c|}{$\mathrm{P}(\mathrm{mg} / \mathrm{g})$} & \multicolumn{3}{|c|}{$\mathrm{K}(\mathrm{mg} / \mathrm{g})$} & \multicolumn{3}{|c|}{$\mathrm{Mg}(\mathrm{mg} / \mathrm{g})$} & \multicolumn{3}{|c|}{$\mathrm{Ca}(\mathrm{mg} / \mathrm{g})$} & \multicolumn{3}{|c|}{ SPAD 值 } \\
\hline & $\mathrm{C} 100$ & P0 & $\mathrm{t}$ & $\mathrm{C} 100$ & $\mathrm{P} 0$ & $\mathrm{t}$ & C100 & $\mathrm{P} 0$ & $\mathrm{t}$ & C100 & P0 & $\mathrm{t}$ & $\mathrm{C} 100$ & $\mathrm{P} 0$ & $\mathrm{t}$ \\
\hline 9 日 & 2.99 & 8.07 & *** & 43.4 & 47.5 & & 1.24 & 1.12 & & 3.7 & 2.7 & $*$ & 52.5 & 53.3 & \\
\hline 17 日 & 1.44 & 2.93 & $*$ & 35.9 & 42.8 & $*$ & 1.26 & 1.14 & & 2.6 & 2.0 & & 51.7 & 55.5 & ** \\
\hline 24 日 & 1.10 & 1.46 & & 33.9 & 38.3 & $*$ & 1.09 & 1.00 & & 2.1 & 1.5 & * & 53.7 & 55.2 & \\
\hline
\end{tabular}

表中の*，**は， t 検定でそれぞれ処理間に $5 \%, 1 \%$ 水準で有意差があることをを示す.

が認められた。これに対して，トウモロコシでは，定植後 17 日目までは処理区間で有意な差は認められなかったが, 24 日後にはP0区で有意に高かった。

\section{5. 茎葉の無機養分含有量}

定植前リン酸苗施用を行ったときの，両作物の茥葉中の $\mathrm{P}, \mathrm{K}, \mathrm{Mg}, \mathrm{Ca}$ およびポット苗キャベッの $\mathrm{N}$ 含有量を第 2
表に，またポット苗キャベツの葉位別の $\mathrm{P}, \mathrm{K}, \mathrm{Mg}, \mathrm{Ca}$ および $\mathrm{N}$ 含有率を第 3 表に, トウモロコシの葉身中の $\mathrm{P}, \mathrm{K}$, $\mathrm{Mg}, \mathrm{Ca}$ 含有率および $\mathrm{N}$ 含有率の指標として最上位展開葉 の SPAD 值を第 4 表に示した.

ポット苗キャベッでは, リン酸処理を行うと, P0区の $\mathrm{P}$ と $\mathrm{K}$ の茎葉の含有量は, $\mathrm{C} 100$ 区に対して高まり，Pの全 調査時期と $\mathrm{K}$ の定植後 14 日後はその差が有意であった。 
葉位別の含有率でみた場合も, 全ての葉位の $\mathrm{P}$ 含有率は P0 区で高かった，特に下位葉ほどその差が大きくなる傾 向も認められた。すなわち, 例えば定植 21 日後では, $\mathrm{C} 100$ 区の $\mathrm{P}$ 含有率が, 第 9 葉で $5.06 \mathrm{mg} / \mathrm{g}$ であったものが, 葉位が古くなるに伴い低下し，第 $1 \sim 2$ 葉では $2.67 \mathrm{mg} / \mathrm{g}$ となったのに対して，P0区では，第 1 9 葉の P 含有率は $5.60 \sim 6.42 \mathrm{mg} / \mathrm{g}$ と C100 区に比べ高かったのに加え, 葉 位間の相違が小さかった，K含有率は，定植後 14 日目ま では P0 区で高くなったが，21 日目には，下位葉を除きそ の差は認められなかった. $\mathrm{Mg}$ と $\mathrm{Ca}$ の地上部含有量には, 調查期間を通じて処理間に明確な差異は認められなかっ た、葉位別の含有率でみた場合は, $\mathrm{Mg}$ 含有率には有意差 が検出されなかったが, 光合成速度の場合と同様に, 処理 と葉位を要因として分散分析を行うと, 定植後 14 日目に は P0 区で有意に高く（リン酸処理 $: p=0.0016$, 葉位： $\mathrm{p}=0.0000$, 交互作用: $\mathrm{p}=0.9864)$, 逆に21日目には C100区で高くなった（リン酸処理 $: p=0.0193$, 葉位: $\mathrm{p}=0.0000$, 交互作用 $: \mathrm{p}=0.7622)$. 一方, Ca 含有率は, 定植後 14 日目には, $\mathrm{Mg}$ 含有率同様に P0 区でやや高くな る傾向があったが，有意な差ではなかったＮ含有量につ いては, 定植 21 日後のデータしかないが, 最下位の第 $1+2$ 葉では C100 区で高かったが, 第 3 9 葉では処理区 の差はほとんど認められなかった。

トウモロコシでは, リン酸処理により茎葉の $\mathrm{P}$ 含有量は 調查期間をとおして高かったが，K含有量は定植 24 日後 にのみ高かった. $\mathrm{Mg}$ と $\mathrm{Ca}$ の茥葉含有量は, 定植 9 日後に は P0 区がC100区より低かった，Ca含有量は，その後も $\mathrm{P} 0$ 区で $\mathrm{C} 100$ 区より低く推移する傾向にあったが, Mg 含 有量は, 定植 24 日後には, 有意差は認められないものの P0 区で高くなる傾向にあった。一方，葉身中の乾物重あ たりの含有率は, P0区の $\mathrm{P}$ 含有率は, 定植 9 日後には C100 区の 2.7 倍にまで高まった，その後その差は小さく なり, 定植 24 日後には 1.3 倍程度まで縮まり, 有意差は 認められなくなったが, 調査期間中はC100区より高く推 移した。また $\mathrm{K}$ 含有率も $\mathrm{P} 0$ 区で高く経過した。これに対 して, $\mathrm{Mg}$ 含有率は処理区間の有意差は認められなかった。 また，Ca含有率は P0 区が C100 区よりも低く推移した. 一方, 葉身の $\mathrm{N}$ 含有率の指標となる $\mathrm{SPAD}$ 值は, 定植後 17 日には P0 区が有意に高かった。

\section{考察}

定植前リン酸苗施用を扔こなった苗を定植すると, 定植 直後の数日間は, 生育促進効果が認められないか, 場合に よってはトウモロコシのように生育抑制的に㗢いた。しか し, 定植後約 1 2 週間には, 両作物とも生育促進の効果 が認められ, トウモロコシではそれ以降も効果が継続した。 したがって，両作物とも，リン酸処理により定植後の 7〜 15 日間程度を扣いてから，それに続く $1 \sim 2$ 週間の生育が 促進されることで, 初期生長量が大きくなることが明らか
となったただし，トウモロコシでは，この間をとおして 根の生育は抑制されたが, その分地上部への乾物の分配が 多くなる特徵が認められた。

また，第 3 図に示したようにポット苗キャベッではリン 酸処理により葉位毎の葉面積がそれぞれ一定の值に達し, 葉身の展開が終了するまでの期間が数日短くなった。すな わち, リン酸処理は生育ステージを前進させたものと考え られた。コムギに定植前リン酸苗施用を行うと, 分げつ数 が定植 23 日後には, 対照区の 2.7 本に対して, リン酸処 理区では 3.1 本に増加し（渡邊ら 2002）, さらに同様の傾 向は，水稲でも移植前にリン酸処理をした場合に認められ ており（渡邊ら 2007），いずれも生育ステージが前進して いたものと考えられた。すなわち, 定植前リン酸苗施用は, 定植直後の生育をやや抑制することはあるものの, 結果的 には活着を促進し, 生育のラグ期間を短縮する効果がある ものと推察された。

初期生育の促進過程を生長解析の結果と照らし合わせて みると, 定植後数日間の生育停滞, およびその後の促進と も NAR の変化と一致した。 すなわち, 定植後 7〜15 日前 後過ぎた頃から葉面積あたりの光合成速度が高まることを 意味する，実際，ポット苗キャベッとトウモロコシでは， それぞれ定植 13 日後, 16 日後には個葉の光合成速度が高 まることが確認できた。しかし一方で，トウモロコシでは， 根の生育が抑制されたことに伴い, 地上部への乾物の分配 が高まり, LARが大きくなったことも, 初期生育の促進に 寄与しており, 初期生育促進の様相には作物種間で違いが 認められた

第 7 図に示したように，定植前リン酸苗施用により光合 成速度が高まったポットキャベッの定植後 13 日目および トゥモロコシの定植後 16 日目において, リン酸処理は, 両作物とも, 気孔コンダクタンスと光合成速度との関係性 には影響しなかったが，気孔コンダクタンスを大きくする ことにより光合成速度も高くしたものと考えられた。すな わち, 両作物とも定植前リン酸苗施用が根の活着を促進し, 吸水が円滑に行われ, 植物体全体の通導抵抗が小さくなっ たことにより，この生育時期の光合成速度が高くなったも のと考えられた

しかし，トウモロコシでは，処理間で回帰定数に有意差 が認められ，同等の気孔コンダクタンスにおいても P0区 の光合成速度が高く, 気孔コンダクタンスの増加以外にも 光合成速度を高める要因が存在することが示唆された。

そこで, 次に葉身の無機養分含有率と光合成活性との関 係について考察したい, 定植前リン酸苗施用により, 光合 成器官である葉身の $\mathrm{P}$ 含有率は, キャベッ, トゥモロコシ とも顕著に高まった. $\mathrm{P}$ は, 光リン酸化反応をはじめとして, 光合成には不可欠な成分であり, 久乏すれば光合成は阻害 される，それ以下では光合成が阻害される葉身の $\mathrm{P}$ 含有率 の臨界值として, トウモロコシでは $3 \mathrm{mg} / \mathrm{g}$ (田中・原 1971), 水稲では $2 \mathrm{mg} / \mathrm{g}$ (Makino et al. 1984), キュウリで 

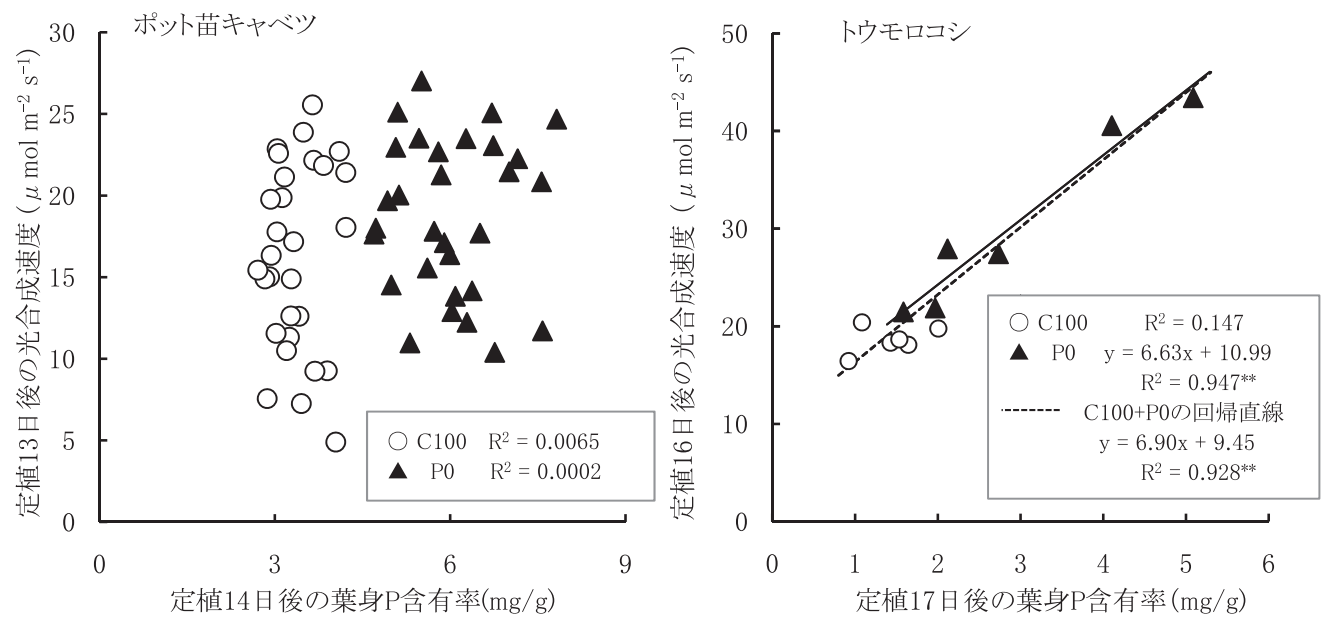

第 10 図 定植前リン酸苗施用を行ったときの葉身 $\mathrm{P}$ 含有率と気孔コンダクタンスと光合成速度との関係. 図中の**は $1 \%$ 水準で有意であることを示す.

は $2 \mathrm{mg} / \mathrm{g}$ （花田ら 1981）などの数值が報告されている. 第 4 表に示したように, 今回の試験で, トウモロコシの定 植後 17 日目の葉身 $\mathrm{P}$ 含有率は, C100 区では $1.44 \mathrm{mg} / \mathrm{g}$ と 田中・原の示した $3 \mathrm{mg}$ を大きく下回っていたのに対して, P0区では $2.93 \mathrm{mg} / \mathrm{g}$ であった。 したがって, トウモロコ シでは，定植前リン酸苗施用により，葉身の P 含有率が高 くなったことも，光合成活性を高くした要因の一つである と考えられた，一方，キャベツについては光合成活性に対 する葉身の $\mathrm{P}$ 含有率の臨界值は不明であるが，他の作物同 様に 2 $3 \mathrm{mg} / \mathrm{g}$ と考えると, キャベッでは C100 区でも定 植後 24 日目の第 $1 \sim 4$ 葉を除いて $3 \mathrm{mg} / \mathrm{g}$ 以上の值であり, $\mathrm{P}$ 含有率が光合成速度を制限することはなかったものと考 えられた。

この点について詳細に検討するために, 定植前リン酸苗 施用により光合成速度が高かったポット苗キャベッの定植 後 13 日目拉よびトウモロコシの定植後 16 日目について, 葉身の $\mathrm{P}$ 含有率と光合成速度との関係を第 10 図に示した。 キャベッの葉身の $\mathrm{P}$ 含有率は, すでに述べたように, C100 区で低く，P0区で高かったが，光合成速度との間には相 関関係は認められなかった。すなわち，葉身 $\mathrm{P}$ 含有率は $\mathrm{C} 100$ 区の最低值でも $2.7 \mathrm{mg} / \mathrm{g}$ で，光合成活性を維持する のに十分なレベルにあったと考えられた，そのため定植前 リン酸苗施用をしたポット苗キャベッの光合成速度の増加 は，葉身の P 含有率の増加には影響されず，主に気孔コン ダクタンスの増加に伴ったものと考えられた。

これに対して, トゥモロコシでは, 葉身の P 含有率と光 合成速度との間に正の相関が認められた。ここで示したト ウモロコシの葉身の $\mathrm{P}$ 含有率は, 光合成速度の測定を行っ ていない下位葉を含む全葉身についての值であることを考 慮する必要はあるが, C100 区では全ての個体で葉身のP 含有率は $2 \mathrm{mg} / \mathrm{g}$ 以下であり, 円滑な光合成活性を維持す るのに不十分であったと考えられた。したがって，定植前 リン酸苗施用が $\mathrm{P}$ の吸収を促進し，無処理苗では不足する
葉身の $\mathrm{P}$ 含有率を高めたことも光合成速度を高めることに 寄与したものと考えられた。

このトウモロコシとキャベッとの葉身の $\mathrm{P}$ 含有率に関す る種間差は，光合成活性に対する定植前リン酸苗施用の効 果がトウモロコシでより大きかった一因であったかもしれ ない.

一方，K 欠乏により光合成が阻害される葉身の $\mathrm{K}$ 含有率 の臨界值として, トゥモロコシでは $15 \mathrm{mg} / \mathrm{g}$ （田中・原 1972)，水稲では $13 \mathrm{mg} / \mathrm{g}$ (Makino et al. 1984）などの数值 が報告されているが，今回の試験で両作物の葉身の $\mathrm{K}$ 含有 率は，C100区でもこれらの值を大幅に上回っていた。し たがって，定植前リン酸苗施用は葉身の K 含有率を高めた が, 光合成活性の向上には直接関係しなかったものと考え られた

さらに，リン酸処理を行ったキャベッでは, 光合成速度

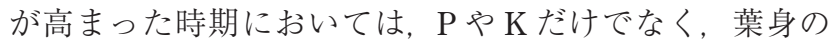
$\mathrm{Mg}$ 含有率も高かった。 今回の試験に打いては, トウモロ コシでは $\mathrm{Mg}$ などの成分の増加は認められなかったが，N 含有率と密接な関係にある SPAD 值はリン酸処理区で高く なっていた。 また，すでに報告したトウモロコシの戋場試 験の結果では，定植前リン酸苗施用により葉身中の $\mathrm{Mg}$ や $\mathrm{N}$ 含有率が増加し，これらと光合成速度の増加との間には 正の相関が認められた（Watanabe et al. 2005）。さらにコム ギでも，定植前リン酸苗施用により茎葉中の $\mathrm{Mg}$ や $\mathrm{N}$ 含有 率の増加が認められている（渡邊ら 2002）。したがって, 定植前リン酸苗施用により $\mathrm{P}$ 以外にも，光合成の必須成分 である $\mathrm{Mg}$ や $\mathrm{N}$ などの吸収が増加することも，光合成活性 の向上を通じて，初期生育を促進した要因の 1 つである可 能性が示唆された。なお, トウモロコシでは, 定植前リン 酸苗施用により $\mathrm{Ca}$ の吸収や葉身の含有率が $\mathrm{C} 100$ 区より 低くなり，Ca の吸収が抑制された可能性が示唆されたが, 光合成やそれに伴う生長を抑制することはなかったものと 考えられた 
このような気孔コンダクタンスの向上，および無機成分， 特にリン酸カリ水溶液に含まれない $\mathrm{Mg}$ や $\mathrm{N}$ などの含有率 の増加は，それぞれ水や無機養分の吸収が促進されたこと を示している。この要因としては，吸収機能をつかさどる 場としての根の伸長が促進されたことと, 吸収機能の活性 が向上したことの 2 つが考えられる.

セル苗キャベツでは，定植前リン酸苗施用により NAR が高かった定植後 15２7 日に関して，根長は，15日目で は処理間に差は認められないものの，27日目にはP50区 で約 2 倍の長さになっており，この間の平均根長は P50 区 で長かったものと推察される。したがって，キャベッでは 根の表面積自体が大きくなったことが，土壤中の水や無機 養分の吸収を促進した要因の一つと推察された。

一方, 根の呼吸速度も, 定植前リン酸苗施用により NAR が高い時期にキャベツでは高かった。トウモロコシにおい ても定植後 17〜24 日に対応する 24 日目の根の呼吸速度は P0区の方が高くなっていた。これに対して，C100区に比 べて P0 区の NAR が最も向上した定植後 9〜17 日に対応す る定植後 17 日目の P0 区の根長，呼吸速度とも C100 区よ り劣っていた。しかし, 出液量は $\mathrm{P} 0$ 区で多く, 呼吸速度 の值からは要因を特定できないものの, 根の生理活性自体 は高かったものと考えられた。居ら（2006）が，水稲では 出液速度が高いほど $\mathrm{N}$ の吸収量が増加することを報告して おり，これと同様，定植前リン酸苗施用が根の活性を高め たことも， $\mathrm{N}$ や $\mathrm{Mg}$ などの吸収を促進した一因であると考 えられた。

一方，津野・山口（1987）が報告しているように，光合 成活性が高まったことにより，根への呼吸基質の転流が増 加し，その結果として根の活性が高くなったという解釈も 可能である。栘田・島田（1993）は，トマトの木部いっ泌 液中の硝酸態窒素, $\mathrm{Mg}, \mathrm{Ca}$ 濃度が，遮光処理により低下 することを報告しているが，言い換えれば，光合成による 同化量が多いほどこれらの無機養分の吸収が増加すること である，先にトウモロコシについて述べたように，定植前 リン酸苗施用により葉身の $\mathrm{P}$ 含有率が増加し，光合成活性 が高くなったとすると，これらが，根への呼吸基質の供給 を増加させ，水や無機成分の積極的な吸収を促進したとい う解釈も可能である.

水や無機養分の吸収促進の結果，光合成活性が高まるこ とと, 光合成活性が高くなったことにより根の水や無機養 分の吸収能力が高まることのどちらが先に起こったかにつ いて，今回の試験結果からは結論を導き出せないが，両者 が互いに関連しながら，初期生育の促進に寄与していたも のと考えられた。

以上より，定植前リン酸苗施用による初期生育の促進の メカニズムについて, 今回の試験結果から結論づけられる のは，以下のとおりである。

定植前リン酸苗施用は，まず植物体全体の $\mathrm{P}$ 含有率を高 め，下位葉を含めた光合成能力を高めるとともに，根の生
理活性を高め, 加えてキャベツでは根の伸長を促進して活 着を早め, 土壤中から水および無機養分の吸収を増加させ る。そして，この十分な水と無機養分の葉身への供給が高 い光合成活性を維持することにより，無機養分の吸収をさ らに増加させるとともに, 初期生長速度が高くなるものと 考えられた。

しかし，定植前リン酸苗施用が根の生理活性や伸長を促 進する直接的なメカニズムについては，今回は明らかにで きなかった。 また，根の伸長阻害が大きかったトウモロコ シは, キャベツに比べて, むしろ生育促進の程度が大きく なっており，作物種による効果の違いについても未解明の 部分が多い。今後は，これらの点についてさらに検証を進 める必要があると考える。

\section{引用文献}

花田俊雄・高橋和彦・長岡正昭・吉岡宏 1981. キュウリ個葉の光合 成に及ぼす $\mathrm{N} \cdot \mathrm{Mg} \cdot \mathrm{P}$ 濃度の影響. 野菜試報 A.9 : 83-96.

居静・ 山本由徳 · 宮崎彰 ·吉田徹志 ·王余龍 2006. 中国産多収性水 稲品種揚稲 4 号の出液速度と窒素吸収量に及ぼす肥料の種類と施 肥量の影響. 日作紀 $75: 249-256$.

Makino A., T. Mae, K. Ohira 1984. Effect of nitorgen, phoshporus or potassium on the photosynthetic rate and ribulose-1,5-bisphosphate carboxylase content in rice leaves during expansion. Soil Sci. Plant Nutr. $30: 63-70$

桝田正治・島田吉裕 1993. トマト木部いっ泌液における無機成分濃 度の日変化抒よびその濃度に及ぼす光照度と葉齢の影響. 園芸雑 $61: 839-845$.

森田茂紀, 阿部淳 1999. 出液速度の測定・評価方法. 根の研究 $8: 117$ -119 .

小原洋・中井信 2004. 農耕地土袞の可給態リン酸の全国的変動, 農耕 地土壤の特性変動 (II).土肥誌 $75: 59-67$.

小柳敦史 1995. 戋場におけるコムギ根系の能動的吸水に影響を与え る諸要因. 根の研究 $4: 39-42$.

Sharpley A.N., T. Daniel, T. Sims, J. Lemunyon, R. Stevens and R. Parry 2003. Agricultural Phosphorus and Eutrophication, Second edition, United States Department of Agriculture, Agricultural Research Service, ARS-149.

田中明 · 原徹夫 1971. 単葉光合成能の栄養生理学的研究. (第 2 報) トウモロコシにおける単葉光合成能とリン栄養との関係. 土肥誌 $42: 300-303$.

田中明. 原徹夫 1972. 単葉光合成能の栄養生理学的研究. (第 3 報) トウモロコシにおける単葉光合成能と加里栄養との関係. 土肥誌 $43: 132-136$.

津野幸人・山口武視 1987. 水稲光合成の高温低下現象と根の呼吸速 度との関係ならびに根の呼吸速度に関与する要因の解析. 日作紀 $56: 536-546$.

U.S. Geological Survey 2010. Phoshate rock. Mineral Commodity Summaries, January 2010. 118-119. http://minerals.usgs.gov/minerals/ pubs/mcs/2010/mcs2010.pdf (2011/2/7 閲覧).

渡邊和洋 · 森谷茂 ·渡邊好昭 ·藤井國博 1997. 定植前重点施用によ るリン酸施用量の削減. 土肥誌 $68: 622-628$.

渡邊和洋・村山徹・新野孝夫 2002. 定植前リン酸施用による初期生 
育促進機構の解析. 1. 定植前リン酸施用により $\mathrm{N}, \mathrm{Ca}, \mathrm{Mg}, \mathrm{S}$ の吸収 が促進される.日作紀 71(別 1) : 58-59.

渡邊和洋 - 渡邊好昭 - 新野孝男 - 新田恒雄 2005. キャベッの定植前 リン酸苗施用によるリン酸施用量の $80 \%$ 削減と土壌の化学性の 変化. 土肥誌 $76: 35-41$.

Watanabe K., T. Murayama, T. Niino, T. Nitta and M. Nanzyo 2005. Reduction of phosphatic and potash fertilizer in sweet corn production by pre-transplanting application of potassium phosphate to plug seedlings. Plant Prod. Sci. 8 : 608-616.

渡邊和洋・新野孝夫・村山徹・南條正巳 2007. 移植前リン酸苗施用 による水稲の初期生育促進. 日作紀 $76: 181-188$.

山口武視, 津野幸人, 中野淳一, 真野玲子 1995. 水稲茎基部からの出液 速度に関与する要因の解析. 日作紀 64 : $703-708$.

Effects of the Pre-transplanting Phosphorus Application on Dry Matter Production, Photosynthesis, Root Activities and Nutrient Absorption of Cabbage and Maize at Initial Growth Stage : Kazuhiro WATANABE ${ }^{1)}$, Takao NinO ${ }^{2)}$, Tohru MurAYAMA ${ }^{3)}$ and Masami Nanzyo $^{4)}\left({ }^{1)}\right.$ Natl. Agr. Res. Cent., Tsukuba, Ibaraki 305-8666, Japan; ${ }^{2)}$ Natl. Inst. Agrobio. Sci., ${ }^{3)}$ Natl. Agr. Res. Cent. Tohoku Region, ${ }^{4)}$ Fac. of Agr., Tohoku Univ.)

Abstract : The effects of pre-transplanting phosphorus application (PTPA) on the initial growth of cabbage and maize were investigated with regard to dry matter production, photosynthesis, root activities, root elongation, and nutrient absorption. PTPA did not promote the growth for a few days after transplanting, but promoted the subsequent growth in both crops. This promotive effect mainly depended on the increase in net assimilation rate (NAR), which coincided with the increase in photosynthetic rate and stomatal conductance. PTPA increased the absorption of phosphorus and potassium which were contained in the applied solution. Increase in $\mathrm{P}$ in leaf blades of maize also contributed to the increase in photosynthetic activity. In some case, PTPA also increased absorption of the other essential elements such as magnesium. Root activities, expressed by root respiration rate and bleeding rate from the stubble, were also improved by PTPA associated with longer root length in PTPA cabbage. These results suggested that PTPA enhanced photosynthesis and root activities, through enhanced P absorption, and it also enhanced root elongation for cabbage, which accelerated the rooting and increased water and nutrient absorption from soil. Sufficient supply of water and nutrients maintained a high photosynthetic rate, resulting in the growth promotion for a few weeks after transplanting.

Key words : Cabbage, Initial growth stage, Maize, Nutrient absorption, Phosphorus, Photosynthesis, Pre-transplanting phosphorus application. 